\author{
$\begin{array}{cl}\text { Ampie Coetzee } & \text { Die vlugtige taal van vergeet: Die } \\ \text { metafoor by Breyten Breytenbach }\end{array}$ \\ Ampie Coetzee is professor-emeritus \\ en was voorheen verbonde aan die \\ Departement Afrikaans en Nederlands, \\ Universiteit van Wes-Kaapland, \\ Bellville. Hy is die skrywer van onder \\ meer ' $n$ Hele os vir 'n ou broodmes: Grond \\ en die plaasnarratief sedert 1595 \\ (Van Schaik, 2000). \\ E-pos:ampiec@mweb.co.za.

\section{Die vlugtige taal van vergeet: Die
metafoor by Breyten Breytenbach}

The transitory language of forgetting: The metaphor in the work of Breyten Breytenbach

From his first book of poetry, die ysterkoei moet sweet ("the iron cow must sweat", 1964), till his most recent one, die windvanger ("the windcatcher", 2007), metaphor has been a central means towards the creation of meaning for Breytenbach. This article will investigate the use of metaphor particularly in this recent book. Theorising will begin at the beginning, at Aristotle's De Poetica and Rhetorica, where "simile" and "metaphor" are seen as the means toward seeking the relationship between signifier and signified. The poem "New York, 12 September 2001" is the focus of this relationship. Here the fallibility of the word in attempting to represent that tragedy (of the 11th) is illustrated. The theme of the poem is stated in its first lines: "will the hand continue to move on paper / will any poem ever have enough power ..." This article eventually comes to the conclusion that Breytenbach's use of the metaphor can be summarised in the words of Aristotle: "It is a great thing indeed, to make proper use of the poetical form [...] But the greatest thing by far is to be a master of metaphor". Key words: metaphor, signifier, signified, relationship.

" $[\ldots]$ the messenger was messenger alone and could tell nothing of the news he bore" (Cormac McCarthy, The Crossing)

1

Teoretisering oor die metafoor vandag sou weinig meer kan sê as wat daar in Aristoteles se De Poetica en Rhetorica, ongeveer 330 jaar V.C. gesê is. Nou is daar eintlik slegs samevattings, teoretiserings en filosofering oor soos in die alomvattende werk van Paul Ricoeur, Rule of Metaphor (1975). ${ }^{1}$ Aanhoudende teoretisering raak uiteindelik self metaforiserend: "The theorist of poetry tends more and more today to make metaphor the irreducible element of his definition of poetry, but in attempting to define metaphor itself he tends furthermore to shoot off into endlessly interesting series of metaphors." (Wimsatt 1954: 128)

Aristoteles se bekende definisie - die beginpunt van die bekendste studies oor die metafoor - lui as volg: "Metaphor consists in giving the thing a name that belongs to something else; the transference being from genus to species, or from species to genus, or on grounds of analogy." (Aristoteles, De Poetica, 1457b, 5-15) 
Mens sou ook kon begin met die omskrywing wat hy gee in die Rhetorica van metafoor en vergelyking:

The Simile is also a metaphor; the difference is but slight. When the poet says of Achilles that he "Leapt on the foe as a lion" this is a simile; when he says of him "the lion leapt", it is a metaphor - here, since both are courageous - he has transferred to Achilles the name of "lion". Similes are useful in prose as well as in verse; but not often, since they are of the nature of poetry. They are to be employed just as metaphors are employed, since they are really the same thing except for the difference mentioned (Aristoteles, Rhetorica, 1406b, 20-7).

Die woord "vergelyking" word in Afrikaans gebruik, en in Engels simile. Laasgenoemde is nader aan die betekenis, omdat dit oproep die woord similitude wat dan in Afrikaans eerder "ooreenkomstigheid" is.

Die onderskeid en ooreenkoms tussen metafoor en vergelyking sal in die loop van hierdie ondersoek bespreek word. Breyten se nuutste digbundel, die windvanger (2007), ${ }^{2}$ sal gebruik word as basis vir die navorsing. Die metafoor is egter vanaf sy eerste bundel - die ysterkoei moet sweet (1964) - 'n deurlopende, en sentrale, middel tot betekenisskepping. die windvanger is 'n metaforiese titel, en so ook die byskrifte en sommige titels van afdelings 1 tot 9 .

As motto by die titel word gebruik'n aanhaling uit die werk van Federico Garcia Lorca. Dié motto is nie in die Afrikaanse uitgawe nie; maar in'n Nederlandse bloemlesing van sy werk, getitel De windvanger: "Door de lege boog blaast een wind, een geestelijk wind die onophoudelijk over die hoofden van de doden waait, op zoek naar nieuwe landschappen en onbekende accenten, een wind die ruikt naar babyspeeksel, gekneusd gras en de sluier van kwallen, en die de voortdurende doop van nieuw gecreërde dingen aankondigt. (De windvanger, motto).

"Windvanger" kan dan gelees word as wind-wat-vang, wat opvang en soek en nuwe skeppings aankondig. Ook soos die gedig wat weerspieël en skep. In Lady One word vir die eerste keer verwys na die gedig as windvanger: "die togte van'n windvangervers in die landskap" (Lady One, 181).

Afdeling-titels en die byskrifte gee' $n$ aanduiding van temas. Hierdie titels is meestal metaforiserend:

1 daar is geen tyd

2 fluit-fluit (tyd is die verskietende komeet van geheue)

3 lappesait (dis die vuur van bestaan wat die ure vertel)

4 najaarsverse (bespikkel en uitgemeet met kankerwoorde van vergeet)

5 reispapier (om die holtes te vul met die vlam van vertel)

6 die hart se dinge (my liefde vir jou, die akkedisbewegings van weggaan)

7 akkediskak (die ewigdurende galmende momentum van stilte)

8 die windvangerlied (stories wat mens nooit weer sal hoor nie) 
9 opsystaan (daardie vele gesigte van vergaan)

(windwanger, 9, 13, 41, 53, 69, 79, 107, 123, 153).

Die temas of onderwerpe van elke afdeling word nou kortliks saamgevat, waar daar metafories, of spesifiek verwysend, te werk gegaan is. Tyd sou mens die hoofmotief van die bundel noem, tyd en geheue wat verbygaan: 1 en 2; en die einde van die storie wat gekom het: "fluit-fluit my storie is uit". (Die tema van verbygaan word weer opgeneem in 8 en 9: die stories wat nooit meer gehoor sal word nie; en die gesigte wat vergaan het; maar veral "vergaan" se gesig.)

Die "lappesait" van 3 verwys na 'n kunsuitstalling wat Breyten in Suid-Afrika gehad het. Die lappesait is die Fanagalo-woord (mynwerkers se lingua franca) vir "hierdie kant". Die "vuur van bestaan...": bestaan is nodig om van tyd te vertel. In "najaarsverse" (4) word die vergeet (wat natuurlik weer verband hou met tyd en die mens se verhouding daartoe), geheue soos in 2, maar nou met die sterwende ("kankerwoorde") van vergeet. Die woord, die gedig op sigself, word nou belangriker. Afdeling 4 begin byvoorbeeld met "Woordfoël se geboorte"; en die gedig as betekenis van die gedig is belangrik hier. Afdeling 5 se titel "reispapier" sou kon verwys na geskrifte oor reis (journey), maar ook met die assosiasie "ryspapier", kunspapier. Die subtitel hier '"om die holtes te vul met die vlam van vertel)" bring weer hier die vertel wat deel van die gedig kan wees; en dan is daar nog die "holtes" waarvoor rekenskap gegee moet word; en dit word gekoppel aan vuur wat vertel. Dan is daar nog "bestaan" en "holtes" waarvoor rekenskap gegee moet word. Die liefde, "die hart se dinge", liefde, is deel van 6, met'n deurlopende metafoor - die akkedis - wat ook titel word in 7 ("akkediskak"). Hier, in 6, is dit die "akkedisbewegings van weggaan". Sou dit kon beteken weggaan wat nie beskryf kan word nie, slegs hoe die weggaan is? Of ook die liefde in die weggaan daarvan? Maar die spesifieke soort beweging van die akkedis is die kern van die beskrywing: hoe die akkedis beweeg. In 7 - "akkediskak" - is die assosiasie nog met weggaan, maar nou banaliseer die metafoor die weggaan. Dit is al wat oorbly wanneer die akkedis weg is, met ander woorde wanneer die bewegings iets van die verlede is - en dan, as motto of bytitel - die paradoksale van'n stilte wat vir ewig galm en beweeg.

Die titel van die bundel word opgeroep in 8: "die windvangerlied". Stories, gedigte; aanvanklik beskrywend, weerspieëlend en dan poësie: lied. “Die laaste gedagte" kom aan die einde (9); nou kan "vergaan" nie meer ver wees nie: die einde van die stories, en van die gedig.

\section{2}

Daar is sekere sleutelwoorde/assosiasies wat deurlopend is in die bundel: verskietende, vergeet, vlam van vertel, weggaan, stilte, nooit weer, vergaan en die dood. Die 
mees frekwente is die ars poetica, en veral die onvermoë van die gedig om die werklikheid te verwoord deur ver-beelding. Die eerste twee strofes van die gedig "nekra" in ('YK'), vertel byna genoeg (want die digter skryf gedurig daaroor):

die gedig is 'n vorm van isolasie

ook die gedig is vol woorde

anders gesê: dis die aanvulling

laag op laag gesekreer (soos 'n skulp)

om die niet te sekwestreer

wat ek skryf is woorde

wat woord ek is skrywe

is om met my ander se kalwers te ploe

en ' $n$ valse ontbloting van die kern

(die woorde koek saam)

die werklike isserigheid bly verdonker

hoe meet jy ook lig met ' $n$ stophorlosie

vervlieting in die dimensie van struktuur? (('YK'), 43).

Die probleem is dat "die werklike isserigheid bly verdonker". Die werklikheid bly nie konstant nie; en, veral: hoe kan die woord die werklikheid weergee? In Voetskrif in een van die teoretiese stukke daarin skryf hy:

(Maar, helaas! "probéér" is juis 'n belemmering.) Is beskrywing (want al skrywende beskryf jy) dan'n uitdrukking van synverkalking? Niks kan in die plek van iets (anders) staan nie. Maar dit kan sóós wees, op voorwaarde dat dit net so lewendig, en aldus onafgerond is, as die ander, die beskrewe beskryfde. (Strukturaliste verwys daarna as die Struktuur agter struktuur. Maar soms is die enigste manier om te weet wat die weer gaan maak die bestudering van die mure se stofskrif [...] (Voetskrif, 54).

Volgens Aristoteles (1451b), is mimêsis poiêsis en is poiêsis mimêsis. Hy maak ook die onderskeid tussen geskiedenis en poësie: geskiedenis is beskrywend (van werklikhede), terwyl poësie "universeel" is; maar 'n digter is 'n digter as gevolg van die nabootsende element in sy werk; en die kreatiewe is onafskeidbaar van die verwysende na die werklikheid (wat hy ook die handelende noem). Dit word saamgevat deur Ricoeur (1975: 290): "The paradox of the poetic can be summed up entirely in this, that the elevation of to fiction is the condition of its mimetic use. Only a feeling transformed into myth can open and discover the world."

Wat hier in verskillende aksente gesê word, kom op'n wyse ooreen met wat al as die direkte en die indirekte in die poësie geïdentifiseer is. E. M. W. Tillyard het die onderskeid gemaak tussen direct en oblique poësie, waar die oblique dan van poëtiese 
middele gebruik maak, soos ritme, simboliek, verwysing - en veral metafoor (Tillyard 1959). Of daar is die onderskeid gemaak tussen die sintagmatiese en die paradigmatiese: "the syntagma is actual and the paradigm is virtual" (Ricoeur 1975: 168).

'n Voorbeeld van die mimetiese en die bespiegelende (Aristoteles se "universele", en Ricoeur se myth) kan in die poësie, in die gedig "Mauritshuis (wat'n kunsmuseum in Holland is) uit die windvanger gelees word. Die gedig begin met 'n beskrywing waarin die spreker rondloop tussen skilderye en dit beskryf wat hy sien:

in 'n museumhuis dwaal jy van kamer tot kamer

en staar van naderby na skilderye vol dooie voëls

pap visse, honger honde, fraai fisante,

veldhere met swierige krae en polsversierings

en ander mense met uitsonderlike hooftooisels

toe daar in Holland nog bosse en heuwels was (windvanger, 143).

Daar is sekere "poëtiese" elemente in hierdie strofe: hoe die spreker die voëls sien, die visse, honde en fisante; en die duidelike assonansie en alliterasie. Maar dit bly hoofsaaklik' $n$ beskrywing: 'n weergawe van die onderwerpe van die skilderye, en 'n herinnering aan die verlede ("toe daar in Holland nog bosse en heuwels was").

In die volgende strofe verander die staar na skilderye tot' $n$ bewuswording van die werklikheid:

die lig wat deur die ruite kom

glim oor donker vloere

Die weerspieëling van die skilderye, die ver-beelding van die digter daarvan, word 'n waarneming gebaseer op die kuns wat gesien word, en dan'n metafoor oor kuns, waarin betekenis gesoek word:

'n kunswerk is 'n flarde gesprek

uitgespoel in die oog - vervagende oorblyfsel

van 'n eenparty-tweespraak [...] (windvanger, 143).

Kuns word verderaan in die gedig gemetaforiseer, en die woord kom óók by:

die gesprek gaan voort

selfs wanneer die betekenis van die woorde

of dalk tot die woordeskat

vervloei het onder vernis

en daar geen bosse of heuwels meer is nie

beeldmakery is immers 'n verdigting

as beskerming teen die tyd, en skep ruimtes

waarbinne daar gesterf mag word (windvanger, 144). 
Beelde maak en dig (ver-dig-ting) - die "verdieping" wat die gedig bring - maak slegs die pad oop tot die dood.

Die werklikheid wat die skilders verbeeld het, word voor die digter se oog gestel; en sy/hy sien dat dit nie werklikhede kon representeer nie: dis die wyse waarop die digter dit sien. Die uiteindelike "betekenis" van kuns is dat dit nie die werklikheid kan "vergestalt" nie - en dan word die metafoor die werklikheid,'n substituut vir die werklikheid.

3

Breyten beskryf dikwels wat voor die oog is, "realisties", maar hy kan die direkmimetiese nie volhou nie, want seeing word by hom telkens seeing as. In Marcus B. Hester (1976: 170) se studie The Meaning of Poetic Metaphor, waar hy Wittgenstein se opvattings oor "betekenis" analiseer, haal hy hom aan: "Seeing as [...] is not part of perception. And for that reason it is like seeing and again not like."

Die sleutel tot Wittgenstein se persepsie van die verskil tussen "om te sien as" en "om te sien" lê in die verwantskap van "om te sien as" tot beelde en die verbeelding (imagination).

Die gedig "Gorée-ure" - daar is drie beskrywings van die eiland Gorée by Dakar, Senegal - is' $n$ waarneming van die vroegoggend wanneer die vissers land toe kom. Eers word vertel dat die waarnemer strand toe gaan om te swem, dan word die koms van die vissers uit die see beskryf, en van die duiwe op die strand, en die katte en die weggooivis, en die brommers. Dan gaan hy - dis klaarblyklik die digter self-terug na 'n binnehof weg van die strand.

Wat hy sien, word vertel, maar feitlik deurgaans hoe hy sien as: die skuite kom "uit 'n skuur van duisternis", "soos iets wat uit die baarmoeder wil breek", die duiwe pik "lugtig", vir die "weggooikatte" wat vir"'n porsie weggooivis / uit die dieptes van die nag" wag, en die brommers drom "briljant" saam. Daar is dan'n wending aan die einde, wat in teenstelling is met die voorafgaande: frangipani-petale wat" soos geurige skerwe oor die keie gestrooi" is, en van' $n$ huwelik wat onthou is. Metafoor - beelding - word deel van die beskrywing, trouens, só deel daarvan dat dit eintlik die metafoor is wat beskryf en wat die betekenis gee.

'n Aspek van die metafoor-familie wat prominent is in "Gorée-ure" is die gebruik van "soos", as die oordrag wat sake wat verbintenis met mekaar het en dan deur dié transposisie betekenis skep. Voorbeelde uit die gedig is die volgende. Van die metafoor self:

[...] wanneer son met silwer munt

die see beslaan [...] (windvanger, 133). 
Die weglating van die lidwoord "die" by son, bring alreeds'n figuurlike aspek, in die sin dat die son gepersonifieer word as handelend. Die bymekaarbring van uiterstes: is die son wat die see "beslaan" (werkwoord), en die "silwer munt" (naamwoord). Die woord "munt" het egter ook verdere konnotasies, as werkwoord, soos "munt slaan" uit die see: die son wat munt slaan uit die see. Dan is daar ook ander betekenisskeppende funksies in die gedig: die vissers wat munt slaan uit die see - én die katte, én die brommers.

Die metafoor gaan verder:

[...] van waar dit nag is, uit 'n skuur van duisternis

kom die eerste boomskuit eiland toe

soos iets wat uit die baarmoeder wil breek (windvanger, 133).

In die eerste reëls hier is daar die koppeling van "waar dit nag is" met "skuur van duisternis". Teenoor die silwer van die see kom die bote uit die donkerte, maar, erger, "duisternis". Dit is egter moeilik om te visualiseer, om voor die oog te sien. Om betekenis te skep uit die metafoor kom daar dus'n kwalifikasie: "soos iets wat uit die baarmoeder wil breek". Die baarmoeder is dan die vergelykingspunt met die boot wat kom uit die duisternis: die gelykmakende, die vergelyking (vergelyking), in Engels simile (similitude). Maar die vergelyking is tog nie dieselfde as die vereniging wat die metafoor bring nie (son met munt ens.).

Is die vergelyking dan nie net' $n$ bevestiging van die metafoor nie; maar hier ook beperkend? Die skepe uit die duisternis is nie uit die baarmoeder nie, maar soos "iets". Dus nie eintlik'n geboorte nie. Die rol van die metafoor as sodanig moet dus verder ondersoek word. Vergelykings met "soos" of "nes" is volop in die windvanger feitlik op elke bladsy, net soos die "suiwer" metafoor - en'n bevestiging van Breyten se vermoë tot betekenisskepping deur die beeld.

Die gedig "dis nie so erg om oneervol uit die stryd te tree nie" begin ook met beskrywing, en dán handeling wat in die wending kom: vergelyking en dan metafoor:

en toe die eerste liggies teen die berg begin flikker

soos die sigaretkooltjies van hulle

wat met dagbreek tereggestel gaan word

en aasvoëls wat swaar flap op soek na vroeë wind,

het ek my weer oor haar gestrek,

en toe sy sug en haar ooglede fladder

het ek gevra, "wat is jou naam?" 


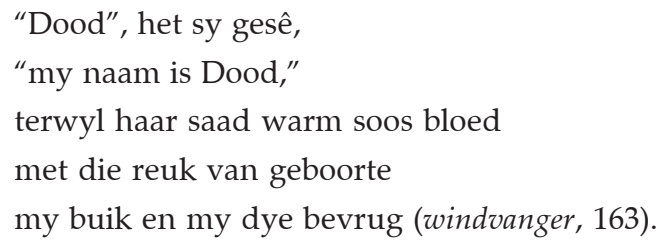

Twee vergelykings: "soos die sigaretkooltjies ..."; en, in die tweede strofe, ("... warm soos bloed"), dán daarna die metafore. Die vergelyking doen dus as't ware die voorbereiding vir die metafoor, en die beelde wissel tussen emotiewe en kognitiewe (bewus uitgedinkte).

Daar is vergelykings wat vanuit ' $n$ metafoor verheldering bring, en dan deur dieselfde vergelyking die tema aanbring (dood, fisiek), en binne dieselfde konteks eindig met' $n$ intuïtiewe, miskien emotiewe, beeld ("in die laat middag"). Hier gaan dit oor die afsaag en wegsleep van 'n sipres. Miskien 'n handeling wat skrei ten hemele:

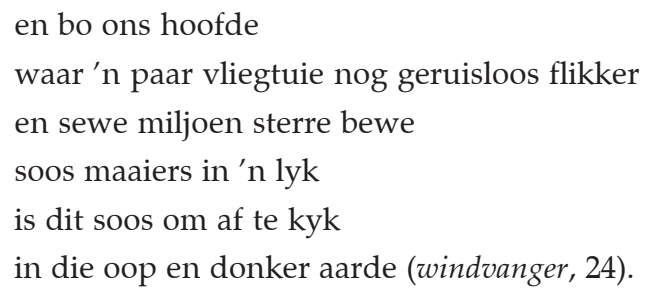

Dis'n gedig wat hoofsaaklik beskrywend is van die afkap en begrawe van 'n sipres, en daarna kyk die "ons" vanaf die kruin van'n berg na die sterre. Die einde van die gedig bring dan sterre - die vergelyking met maaiers - en aarde bymekaar. Die "afkyk" verwys na die afgekapte, begrawe sipres, en dan is daar die "donker wortels wat nou gaan versmoor". Hierdie beeld moet mens dan ook waarskynlik kognitief begryp: die beskrywing-pas-toepassing-patroon.

Die opbou van beelde is waarskynlik kognitief: op die patroon van die beskrywing plus toepassing. Beelde wat verhelder - of verdonker na gelang van die konteks.

Verruiming van betekenis kom deur die beelde: hoofsaaklik deur'n parallel met die dood van die boom en die donkerte van die aarde.

Die vergelyking. Dis nodig om vas te stel of daarin iets soos'n patroon van betekenisvorming is. Dis natuurlik' $n$ vrugtelose soeke; in hierdie soort poësie is daar geen patrone nie. Maar die wisselwerking tussen vergelyking en "suiwer" metafoor is tog betekenisvormend. 'n Mens sou geneig wees om die metafoor as "suiwerder'" te beskou as die vergelyking, omdat dit gekonsentreerd is; vereenvoudig gestel,' $n$ vergelyking afgekort. Die metafoor as substituut. Dikwels - maar nie altyd nie - kan die aanwyser (bv. "soos") van die vergelyking uitgelaat word, en dan is daar geen onder- 
skeid tussen vergelyking en metafoor nie. Dis moontlik dat die metafoor met die vergelyking begin.

Hier is enkele voorbeelde van gevalle waar die vergelyking en die metafoor één kan wees as die sintaksis van die uiting effens gewysig word:

[...]'n eerste veegsel lig bo Oosrivier

soos die herinnering uit ' $n$ ander verder land (windvanger, 64).

Dit sou kon wees: "'n eerste veegsel lig bo die Oosrivier/ die herinnering uit'n ander verder land". Dan word "veegsel lig" en "herinnering" een metafoor. Waarom dan die vergelykingsverbinding. Of is die "soos" 'n beklemtoning van die "veegsel lig"?

Ook:

ek droom my mond

teen joune wat so rooi is

en jou lyf so koel soos vuur (windvanger, 99).

Wat van: "en jou lyf koel vuur" (wat meer in die styl van Breyten se metafore is)? Maar die alliterasie - die "versiering" - van "so" en "soos" gaan dan verlore.

'n Laaste voorbeeld:

liefdesdag

die hemel oop

die stad lê oop

soos 'n ou geheim (windvanger, 100).

of: "die stad'n ou geheim/lê oop"?

\section{4}

Dis opvallend dat die meeste vergelykings in die windvanger elemente van' $\mathrm{n}$ ars poetica bevat. Dit is die problematiek van die poëtiese woord wat al vir meer as 50 jaar by Breyten spook: hoe kan die woord, wat maar teken is, by die betekende, die uiteindelike vasstelling van die werklikheid, uitkom?

Hierdie ontoereikendheid van die woord was ook by ander soekers na betekenis anderkant die gebrekkigheid van die woord. Uit sy bundel Tristia kom'n gedig van N. P. van Wyk Louw (1962: 10) by die volgende uit:

sondaar sonder sonde

(deur vermindering

van klinker - klinkding! - woord-eind)?

Maar so 'n speel maak hierdie klank

iets minder as die táák is:

die offerbrand se stank. 
en:

Wat ek van mense of van God wil meen

word in my dofheid dof.

Iets staan in sterre-en-helderte geskryf;

en ek skryf ná in stof. (Louw 1962: 12; oorspronklike kursief);

en:

[...] in woorde, wat

maar klank en teken is,

in nágeskape skeppinge

die skepping van die god

déúr-dink, déúr-praat. (Louw 1962: 35).

Die uiting by Breyten in een spesifieke gedig is anders, skokkend anders, maar die onbereikbare is weersinswekkend. Nadat hy'n notaboek met verse verloor het, reageer die digter as volg:

bygaande kamerverse

was ingebed in die notaboek

[...]

wat ek ná 'n verdonkering se gefuif in Seattle

in die New York-taxi iewers

tussen die lughawe en die stad

van torings vergeet het

soos 'n klont koue kots [...] (windvanger, 26).

In 'n paradoksale vergelyking, in 'n ander gedig ("toe sê die dief vir die vrou en die kind"), vertel die dief hoe die gedig sy honger en dié van vrou en kind sal stil:

toe sê die dief vir die vrou en die kind

ek weet julle voete en harte is seer

ek is jammer ek het julle verkeerd voorgesê

maar dit belowe ek weer

op my eer as dief

as ons honger word vir liefde

steel ek 'n hele brood lewe

so groot soos 'n gedig

en so voedsaam soos vis (windvanger, 19).

Die ironie begin by die honger; maar honger vir die liefde, want daar is nie kos nie. Vir die liefde sal hy'n brood lewe steel met die gedig as die vergelykingspunt vir dinge wat onvergelykbaar is. Die brood en die vis is ' $n$ assosiatiewe vergelyking, maar 
ook'n implisiete metafoor vir die brood en vis wat'n menigte kon voed; ook dan'n simbool van Christus se goddelike vermoë. Die gedig en die vis, wat nie kos kan wees nie, nie voedsaam kan wees nie, word met die Bybelse voeding vergelyk - wat ook nie noodwendig werklike brood en vis is nie. Alhoewel dit waarskynlik' $n$ intuïtiewe vergelyking is, het dit deur metaforisering'n paradigmatiese element gekry wat die mag van die gedig voorstel in twee vergelykings om die waarde daarvan te probeer bevestig. Maar' $n$ dubbele vergelyking, omdat dit' $n$ poging is om te oortuig: die een is nie so goed nie, daarom nóg een. Die gedig sal dan nie voeding wees nie - minder as'n "klont koue kots".

Die paradoksale redusering van die gedig word voortgesit in vergelykings met die dood as punt:

[...] sal jy getrou kom rou, kreng,

op die grag van papier

wanneer hierdie woorde al donker,

soos ou beendere gis in die grond (windvanger, 45).

Gis is egter nog lewe; maar ou beendere is dood, en die woord "kreng" beteken ook kadawer; die vergelyking is dus "vals", so vals soos die gedig.

Uiteenlopende dinge soos die volgende word in die gedigte wat al hier genoem is, bymekaargebring: "verlore gedig soos'n klont koue kots", "liggies soos sigaretkooltjies", "'n lyf koel soos vuur", "woorde donker soos ou beendere gis in die grond", "brood so groot soos'n gedig", "'n stad soos'n ou geheim" (windvanger, 26, 163, 99, 45, $19,100)$. Die vergelykings bring ander fasette, ander betekenisse tot werklikhede; verbreed die werklikheid, maar verwar ook, sodat beskrywings nie altyd helder is nie - soos betekenis. Byvoorbeeld: om 'n gedig met kots te vergelyk, sal jy eers assosiatief moet lees - om te kan verstaan. Die assosiasie is pejoratief. Waarom juis "koue kots"? Die realiteit van die koue kots word in die gedig gegee in die voorafgaande "[...] ná'n verdonkering se gefuif $[\ldots]$ ". Maar daar is méér in die metafoor. Is daar' $n$ verbintenis tussen "verlore" en "koue kots"? Om die assosiasie verder te soek: verlore is verby; kots is die uitwerpsel van iets wat verteer is, maar nie heeltemal nie; Soos'n onklaar gedig? En "klont" en "gedig"? Mens sou dit tot in die absurditeit kon uitbrei. Maar dit wat sal oorbly, is: 'n verlore gedig is uitwerpsel, en weersinwekkend. Dit is die vergelykings wat hierdie ervaring oordra. So sal elke vergelyking hier'n beskrywing gee; wat in die eerste plek deur assosiasie gemaak is: van dinge wat ver van mekaar af is; maar ook nie noodwendig nie, soos "liggies soos sigaretkooltjies". Die vergelykingspunte is nader aan mekaar, in terme van'n gemene deler (lig en vuur); maar dan kom die paradigmatiese by: assosiasies met vuur, wat dan'n interpretatiewe element inlei.

Die metafoor, emotief en kognitief, intuïtief en bedag, weerspieëlend en interpretatief, as uitdrukking van ontnugtering en reddeloosheid, is dikwels die instrument in die soeke na' $\mathrm{n}$ ars poetica. Vergelyking (simile) is, soos gesien, deel van metafoor. 
Die begin van die beskouing daaroor lê in die konsep van mimesis, wat alreeds genoem is in die bespreking van die gedig "Mauritshuis". "Metaphor is the trope of resemblance par excellence" (Ricoeur 1975: 205). Mens sou verder kon gaan en sê dat die metafoor' $n$ poging is om as beskrywing so na as moontlik' $n$ ooreenkoms te vind met die realitiet, 'n "korrespondensie" wil skep. Hierdie "korrespondensie" word as volg deur W. K. Wimsatt (1967: 251) omskryf:

[...] but looked at internally and verbally, this correspondence consists of a coherence between subject and predicate. They go together. Poetry is a complex kind of verbal construction in which the dimension of coherence is by various techniques of implication greatly enhanced and thus generates an extra dimension of conrrespondence to reality, the symbolical or analogical. But all this structure of meaning rises upon a certain element of unavoidably direct reference to outside reality and minimal truth of such reference.

Om te aanvaar dat metaforiese beelding verband hou met die realiteit sou filosofiese ontledings verg oor die verhouding van gedig tot realiteit, en spesifiek wat "realiteit/ werklikheid" is. Hier word egter versigtig en tentatief aanvaar dat daar verwysings tot spesifieke realiteite is, omdat die woord as teken - en slegs teken - verwys, en ook realiteite kan skep deur die intuïtiewe en kognitiewe vermoë van die digter om diverse sake bymekaar te bring. Die wyse waarop die bevryding van verwysing as slegs verwysing na buite geskep word, bring die betekenis en die estetiese - en as mens dit sou kon waag om te sê: die waarheid.

In die begin van die gedig "feedback" in die bundel (' $Y K^{\prime}$ ') stel Breyten dit in sy besondere siening van die spieël as weerkaatsing van die realiteit - wat die woord ook wil wees:

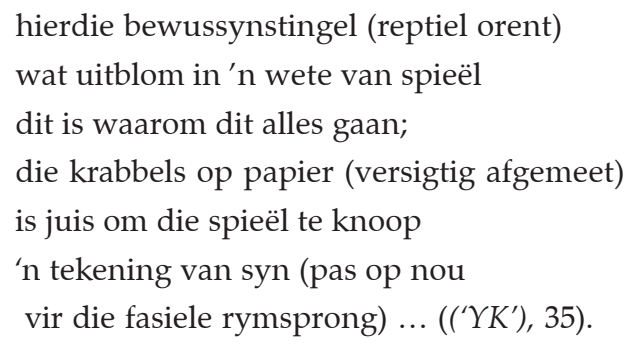

Hoe realiteit, skryf en gedig integreer, kan geillustreer word in dié kort gediggie uit die windvanger (109), "gedigte":

'n gerfie erfgoed,

werfgesels wanneer die son

soos die sang van die swaan

in die weste bloederig swig

voor die gloedlose sekelmaan, 


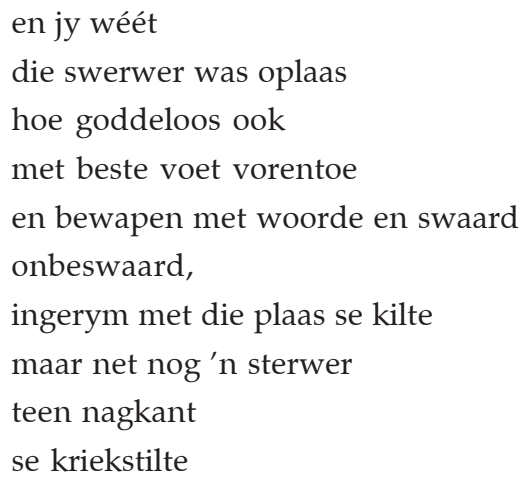

Die werklikheid waarna die gedig verwys, is die geselsery op die werf van 'n plasie, met sonsondergang en skemer. Die swerwer (soos die digter hom sien), die reisiger, dan die gedig, ervaar en neem saam (die "windvanger") die gesels op die werf. Hy neem waar die koms van die aand, en word, in die woorde van die gedig, teen nagtyd deel van die plaas. So sou mens die "uiterlike", die milieu, kon lees.

Die wyse waarop dit meegedeel word, waardeur dit beskryf word, is egter deur die middele van die gedig: ritme, assonansie, alliterasie; maar veral vergelyking en metafoor. Vergelyking van die sonsondergang "soos die sang $[\ldots]$ ", wat oorgaan in metafoor: "[...] bloederig [...] gloedlose sekelmaan". 'n Gewaagde oorgang van vergelyking na metafoor, maar die swerwer, "bewapen" met woord en wapen (gereed), word teen die aand ingewy tot die plaas: met gedig en al. Maar sterf (metafories) soos die dag "teen nagkant/ se kriekstilte".

Die laaste beeld, "kriekstilte", is metafoor, en dit verwys sinesteties, paradoksaal, op die wyse van die gedig, 'n ars poetica: hoe die werklikheid van die plaas en die swerwer "ingerym" word deur die gedig. Wat is "kriekstilte"? Die skielike oomblik wanneer' $n$ kriek vir'n oomblik ophou kriek? Of is die stilte van die kriek juis sy geraas? Die gedig is stilte, én geraas.

Voordat' $n$ voorbeeld gebruik word vir' $n$ finale illustrasie van die werking van die metafoor, is dit nodig om 'n kernaspek van die metafoor te bespreek.

Die betekenis van die woord "metafoor" - "meta-foor" - is oordrag, van'n werklike feit tot' $n$ figuratiewe betekenis, Dit lei dan tot' $n$ oordrag van betekenis, teenoor die vergelyking waar al die woorde hulle betekenis as representasie behou (Ricoeur 1977: 75). As daar'n oordrag van betekenis is, is die metafoor dan'n substituut vir dit wat beskryf of ervaar word - ook dan 'n semantiese afwyking: " $[\ldots]$ substitution $[\ldots]$ is inseparable from the definition of metaphor a deviation in naming" (Ricoeur 1977: 75). Dit plaas die metafoor dan op die paradigmatiese vlak, en nie op die sintagmatiese nie.

Hierdie siening van die werking van die metafoor kan getoets word na aanleiding van metafore uit die vorige gedig ("gedigte"). Die son wat "bloederig swig", byvoorbeeld, of die "gloedlose" sekelmaan, of "ingerym", of "kriekstilte". Die son kan nie in 
gewone taal anders geteken word as "son" nie. Maar met die metafoor kom daar'n pejoratiewe betekenis, wat' $n$ afwyking bring van die gewone betekenis van son, en dit vervang met bloederig en swig. So ook met die flou sekelmaan. Die metafoor "ingerym" kan beteken "ingewy" of "deel gemaak van"; 'n substituut vir "deel gemaak van", "deel word van", selfs "plek ingeruim vir". Die metafoor dra' $n$ veelvoud van betekenisse oor tot één woord. So ook "kriekstilte".

In die laaste gedig van die bundel, "Die laaste gedagte" (windvanger, 177-8), word die vraag na wat die "ek" is gemetaforiseer, oorgedra in verskillende metafore, gesubstitueer om 'n betekenis te vind:

Wat sal die laaste gedagte wees? Wie sal dit dink?

Die ek is 'n ineenstortende samestelling wat oopgaan op ' $n$ beierende

niet van waar'n gewaarwording gebore word wat afhanklik is van "ek"

om tot' $n$ wete te kom.

Die gedig "New York, 12 September 2001" uit die afdeling "Najaarsverse", en waarskynlik die hoogtepunt van die windvanger is ' $n$ poging om te vertel van die terroristeaanval in New York, op die 11de September 2001.

New York, 12 September 2001

"Then it went dark, Real dark, Like snow", woorde van 'n oorlewende.

sal die hand aanhou beweeg oor die papier

sal enige gedig genoeg gewig kan hê

om 'n vlugstreep te laat oor 'n verlate landskap

ooit genoeg van 'n gesig kan lig teen die dood se donker stilte

wie sal dan vertel

hierdie groot miershoop van mense is geskil vandag

somber en skel, helder en beneweld

asof die bruin vuig van sputterende torings

nog soos 'n vuil vlag die luglyn veeg 
beelde bly kerm om uiting agter die oog vliegtuie is bomme vol skrapnel van sagte lywe dan die inferno van vlamblomme uit wolkekrabbels mensfakkels soos neerstortende engele uit die hoogste verdieping af, af, al langs glimmende geboue van glas en staal gewigloos en slank en vuurwerk vaartbelyn verskietend weerspieël in die vlugtige taal van vergeet die helhond van vernietiging het 'n rooi lagtong

wie sal vertel en wie sal kan tel die oog verstaan nie die hemel is blou deur die tries en kil winter van die atoom strompel mense skuifel mense kruip mens-mense waar lê die gesigte oud voor hul jare of die egtelike verbintens van skedel tot tone grys van as asof geklee en gelys in die jas van eeue se sneeuende kennnis

onder rommel en puin mompel en roer rosige lyke en in die Oosrivier dryf vertroulike lêers en flardes en vere verskeurde mensvleis verskroeide confetti van die hond se fees

waar is die gesigte

sal die tong nog kan dink môre môre

in die donker hool nog kan klop

met die vlammende geheue aan vreugde

sal enige gedig eendag iewers ooit genoeg gewig mag hê

om 'n handskrif te laat wat praat van val en vergeet

sal die dood aanhou ritsel in die papier (windvanger, 56-7)

Die eerste opvallende feit van die gedig is dat die stellings wat gemaak word, soos vrae lyk, maar dit nie is nie. Dus retoriese stellings, wat geen antwoord verwag nie; maar dit is nóg vrae. 'n Monoloog, waar die digter, moedeloos oor die onmag van woorde, verstom, vir homself dié dinge sê. ${ }^{3}$

Hierdie gebeurtenis word vertel, dus beskryf; en soos voorheen gesien, is beskrywing mimeties, weerspieëlend, en deurstrengel met metafore. Die gewone beskrywing is nie genoeg nie: die hulpmiddels van metafore (ook vergelyking) is nodig; en die metafoor bring verruiming van betekenis deur die intuïtiewe en kognitiewe byeenbring van eendersheid in andersheid. Dit illustreer die titel alreeds. Maar die 
eendersmaak van andersheid gebeur eintlik nie hier nie, omdat, deur die aard van die vergelyking behou albei woorde hulle semantiese waarde - "dark" en "snow" bly donker en sneeu; daar word nie getransformeer nie (soos "dark snow" byvoorbeeld). Die vergelyking wíl die paradoksale van donker soos sneeu behou. Die paradoksale word dan een van die middels tot betekenisskepping uit die verskrikking.

Die beeldende, vertel van die tragedie is hoofsaaklik deur middel van die metafoor - en daar is gemiddeld vier metafore per strofe.

Dit sal nie moontlik wees om alle metafore en vergelykings hier te bespreek nie; maar oorsigtelik kan daar hopelik'n aanduiding gegee word van die werking daarvan. Maar hierdie "samevatting" en die "interpretasie" sal natuurlik die metafoor reduseer, en van betekenis ontneem. Dít is die waagkans van interpretasie.

Die eerste metafoor wil vasstel of enige gedig gewigtig genoeg kan wees om 'n merk te kan maak, om teen die dood te kan staan. As die gedig nie kan nie, dan kan daar nie - soos die geskiedenis dit sal rapporteer - van so'n verskrikking "vertel" word nie. Die vertel moet dan ook die middel tot vertel wees - en daardie middel is metafoor.

Die gedig wil dan "voor die oog" bring. Wat sien jy? 'n Miershoop wat "geskil" word; en dié werkwoord kan slegs een betekenis hê: afskil soos 'n vrug. Maar dis twyfelagtig of die woord "skil" binne daardie konteks hier pas: die betekende word dus oorskry. Ricoeur (1977: 292) sê iets daarvan: "In service to the poetic function, metaphor is that strategy of discourse by which language divests itself of its function of direct description in order to reach the mythic level where its function of discovery is set free."

Die miershoop-beeld kry wel referensiële betekenis: van mier-werkers wat binne in rondkruip. So is die mense binne hierdie hoop geboue, sou mens die metafoor kon omskryf deur middel van vergelyking. Maar die mense is nie soos nie: hulle het miere geword. Die volgende reël met "somber", "skel", "helder", "beneweld" is nie'n direkte kwalifisering van die metafoor nie; maar werk wel met'n ander soort metafoor: die sinestetiese, die korrespondensie wat gemaak word tussen die sensoriese en die semantiese. Die gevoel wat veroorsaak word deur die mense-miere. Die koppeling van woorde deur alliterasie en assonansie (miershoop, mense, geskil, somber, skel, helder, beneweld) is' $n$ poëtiese middel wat' $n$ verbintenis maak. Nie die betekenaar-betekende verwantskap nie, maar die poëtiese teken. Hierdie tipe betekenaar word voortgesit deur die prominensie van assonansie in die volgende twee reëls: vuig, sputterende, vuil, vlag, veel. Dan gaan die metafoor ook oor in die vergelyking. Nóg'n konvensionele poëtiese middel.

Maar dis asof hierdie gebruik van betekenaars nog nie kan help met die "vertel" nie; want die beelde wil nie uitkom nie ("beelde bly kerm [...]") - die beelde bly "agter die oog" en kom staan nie voor die oog nie. Wat wél volg is die voor-die-geestesoog sienbare: die visuele van bomme, vlamblomme, mensfakkels; weer terug tot die metafoor waar verskille saamkom ter versterking van betekenaars. Die metaforiese betekenisse 
van die vallende mense word bevestig deur die paradoks: die vergelyking-dus: "soos" - van mense met vallende engele; én dan die ironie van die mense wat voorheen miere was, is nou "gewigloos [...] slank [...] vaartbelyn", dus eintlik mooi: engele. Dit word weerspieël in taal (in die gedig), maar ook nie werklik weerspeël nie, want die taal is "vlugtig" en die taal is "vergeet". Die gedig word dan eintlik gedekonstrueer tot niks. Maar dán in hierdie selfde taal word die vernietiging gemetaforiseer in "helhond". Die "vlugtige taal van vergeet" streef na'n betekende wat die voorafgaande metafore in iets "dingliks" substansie kan gee. Maar tevergeefs: die wending-tot-betekenis bly by die metafoor. Die omvang van die vernietiging kan nie weerspieël word nie.

Die onvermoë om hierdie gebeurtenis te weerspieël word herhaal in die volgende strofe ("wie sal vertel [...]"). Die oog kan nóg nie sien nie; kan nie verstaan nie. Hieronder, en in hierdie tries en koue winter "kruip mense-mense" - en nie meer miermense nie - maar ook, en weer in die vorm van die metafoor, metonimies: gesigte vir mense. Mens-mense en hulle gesigte, vroeg-oud, en met gebreekte liggame. Die "as" in die sewende reël van die strofe koppel assonerend, maar nie semanties nie, met die "asof geklee en gelys (?) in die "jas" van die volgende reël. Kennis van sneeu (sneeuende kennis), kennis wat sneeu, wat terug kan verwys na die motto met die paradoksale vergelyking van sneeu en donker. Kennis van sneeu, van die mens wat val. Die paradoksale en woordspel is weer'n middel van die poësie.

In die volgende strofe berus die beskrywing geheel-en-al op die metafoor van wat die mens-mense is: mompelende, rosige lyke, verskeurde mensvleis. Die einde van die strofe stol weer in die paradoks: die betekenislose van verskroeide confetti, en die leë betekenaar weer van die hond.

Hiermee kom finaliteit en'n slotsom; wat nie uit vrae bestaan nie, en wat dus die oënskynlike vrae in die eerste, vierde en hierdie laaste strofe in perspektief stel; en die vrae stellings - eerder uitdagings - word binne' $\mathrm{n}$ sintaktiese patroon van, sê my, wys my, oortuig my hoe" sal die hand aanhou beweeg [...]"; sê my: "wie sal vertel [...]"; wys my waar die gesigte is; sê my of "enige gedig eendag iewers ooit [...]" wys my of daar'n gedig, 'n handskrif, kan wees wat so praat dat die dood altyd in die skrif sal aanbly.

Dis binne die styl van die outydse retoriek wat stellings maak sonder om reaksie te verwag. Die retoriek word dan'n poëtiese middel.

Daar is deurgaans verwys na die middele van die poësie wat in hierdie gedig "ingespan" word. Buiten die modus van die metafoor wat die aard van die gedig bepaal, is daar alliterasie, assonansie, herhaling, metonimie, paradoks, retoriek, en daar sou ook'n definitiewe strofestruktuur vasgestel kon word. Maar daar is ook gedurige wendings: beskrywings, pogings tot weerspieëling, en dan wendings tot' $n$ refrein ("wie sal $[\ldots]$ ", "waar is $[\ldots]$ ").

'n Leser van Breyten se poësie kan geneig wees om te voel dat daar nie genoeg struktuur is nie, dat hy nie "vormvas" is nie; maar tog het hy ook sonnette met'n vaste struktuur geskryf. ${ }^{5}$ 
In die gedig "New York, 12 September 2001" is daar in sommige reëls'n onmiskenbare ritme, wat selfs oorloop tot'n spesifieke metrum. Byvoorbeeld:

sál die hánd áánhou bewéég oor die papiér

sal énige gedíg genoég gewíg kan hê

$[\ldots]$

óóit genoég van 'n gesíg kan líg teén die dóód se dónker

stílte

wié sal dán vertel

Die ritme is opvallend, so ook die assonansies en alliterasies. Daar is ook meer voorbeelde van ander klankherhalings in die gedig. Dit saam met die ander genoemde middele beteken dat die gedig as gedig beklemtoon is, want daar word gesoek na' $n$ gedig wat kan vertel. Maar dit kan nie vertel wat gebeur het nie: die boodskap is ter wille van die boodskap. Die betekenaar sonder betekende: die stil betekenaar.

Die gedig as gedig word dan óók metafoor vir die onvermoë om te vertel van wat gebeur het op die 11de September in New York. Die onvermoë van die gedig om verby die betekenaar te kom, sê ook die stilte daarvan. Ricoeur (1977: 170) se aanhaling uit die werk van Roman Jacobson sal kan aanvul: "Poeticalness is not a supplement of discourse with rhetorical adornment but a total re-evaluation of the discourse and of all its components whatsoever." Ricoeur (1977: 170) se kommentaar op hierdie siening is: "The message is accentuated at the expense of the referential function. Because the message is centered on itself, the poetic function prevails over the referential function."

Oor die metafoor by Breyten is alles by verre nog nie gesê nie. Die rol van die lewende metafoor in sy poësie kan saamgevat word in die woorde van Aristoteles: "It is a great thing, indeed, to make a proper use of the poetical forms [...] But the greatest thing by far is to be a master of metaphor. It is the one thing that cannot be learnt from others; and it is also a sign of genius, since a good metaphor implies an intuitive perception of the similarity in dissimilars" (Poetics 1459a, 3-8).

\section{Aantekeninge}

1. Die vertaling van La métaphore vive is verwarrend. Dit moes miskien eerder "Die lewende metafoor" gewees het; of dan "Die heerskappy van die metafoor".

2. Omdat meer as een werk van Breyten in hierdie artikel gebruik word, sal daar as volg verwys word: (windvanger, en dan die bladsynommer).

3. Die retoriek as poëtiese middel binne sekere omstandighede kan nie uitgesluit word nie. Maar dis 'n ander kwessie.

4. Die aanhaling vroeër in hierdie teks uit Voetskrif (41) is hier van toepassing: "Niks kan in die plek van iets anders staan nie. Maar dit kan sóós wees [...]."

5. In die versameling Lady One (115-9) is daar ses sonnette. Almal bestaan uit 14 reëls, óf Shakespeareaans óf Italiaans, met beskrywing en wending, alhoewel die oorgange tot die wending nie so markant is as in die konvensionele sonnette nie. Daar is selfs rymende sonnette - sowel as 'n spesifieke metrum. 


\section{Bronnelys}

Rhys Roberts. De Poetica Ingram Bywater. Oxford. Clarendon Press.

Breytenbach, Breyten. 1964. die ysterkoei moet sweet. Johannesburg: Afrikaanse Pers Boekhandel.

. 1976. Voetskrif. Johannesburg: Perskor-Uitgewery.

1983. ('YK'). Emmarentia: Taurus.

2000. Lady One. Kaapstad: Human \& Rousseau.

2007. die windwanger: Kaapstad. Human \& Rousseau.

Hester, Marcus B. 1967. The Meaning of Poetic Metaphor.Den Haag, Parys: Mouton \& Co.

Louw, N. P. van Wyk. 1962. Tristia. Kaapstad: Human \& Rousseau.

McCarthy, Cormac. 1998. The Crossing. Londen: Picador.

Ricoeur, Paul. 1978. The Rule of Metaphor. Londen, New York: Routledge.

The Works of Aristotle. 1971. Vert. W. D. Ross (red.). Volume XI. Rhetorica. Oxford: Clarendon Press.

Tillyard, E. M. W. 1959. Poetry Direct and Oblique. Londen: Chatto \& Windus.

Wimsatt, W. K. 1970. The Verbal Icon. Studies in the Meaning of Poetry. Londen: Methuen \& Co. 